This is an electronic reprint of the original article. This reprint may differ from the original in pagination and typographic detail.

Author(s): Ojala, Arto

Title: $\quad$ Business models and opportunity creation: How IT entrepreneurs create and develop business models under uncertainty

Year: $\quad 2016$

Version:

Please cite the original version:

Ojala, A. (2016). Business models and opportunity creation: How IT entrepreneurs create and develop business models under uncertainty. Information Systems Journal, 26 (5), 451-476. doi:10.1111/isj.12078

All material supplied via JYX is protected by copyright and other intellectual property rights, and duplication or sale of all or part of any of the repository collections is not permitted, except that material may be duplicated by you for your research use or educational purposes in electronic or print form. You must obtain permission for any other use. Electronic or print copies may not be offered, whether for sale or otherwise to anyone who is not an authorised user. 


\title{
Business Models and Opportunity Creation: How IT Entrepreneurs Create and Develop Business Models Under Uncertainty
}

\author{
Arto Ojala
}

\begin{abstract}
How can entrepreneurs develop business models for markets in which the technology is constantly changing - or create business models for markets that do not exist? These are fundamental questions for information technology (IT) entrepreneurs, and for information systems (IS) scholars who seek to develop a theoretical understanding of business models. The case study presented in this paper addressed these questions, demonstrating how a small software firm developed its business model over a 15-year period in cloud gaming markets. Based on the empirical findings, a preliminary theoretical model is presented. The aim of the model is to increase scholarly understanding of how business models are created and developed in markets in which the future directions of a technology are uncertain. It demonstrates the ways in which a business model may evolve through reassessment and development phases, which can be seen as transition elements linking old and new business models.
\end{abstract}

Keywords: business models, opportunity creation, business model creation, business model evolution, cloud gaming

\section{Introduction}

New information technologies provide opportunities for IT entrepreneurs. However, it is sometimes hard to predict how the technology will evolve (Adomavicius et al., 2007, 2008; Arthur, 2009; Sood et al., 2012). The new technology may turn out to be a failure, or it may develop in an unexpected direction (Rosenberg, 1998). Thus, IT entrepreneurs have to act under conditions of great uncertainty when they plan their business models. The fundamental question here is: How do IT entrepreneurs create and develop their business models in an environment in which both the technology and the markets are uncertain and constantly changing? 
The existing literature provides a rich body of knowledge on various components to be included in a business model (e.g. Al-Debei and Avison, 2010; Hedman and Kalling, 2003; Osterwalder et al., 2005; Osterwalder and Pigneur, 2010; Zott et al., 2011) and on how entrepreneurs develop their products on the basis of a business model (Blank, 2013; Ries, 2011). Yet even if these contributions reveal the importance of "initial planning" (Blank, 2013), "vision" (Ries, 2011), and "design" (Osterwalder and Pigneur, 2010, 2013), they do not give detailed information on how entrepreneurs create opportunities, or on how these opportunities lead to new business models. "Lean" product and business development has been well elaborated in the works of Blank (2013) and Ries (2011). However, the focus in these studies has been on agile product development on the basis of customer feedback and learning, whereas other important components of a business model (such as a firm's value network, value delivery, and revenue model) have not been given much attention. Furthermore, most descriptions of business models (e.g. Blank, 2013; Osterwalder and Pigneur, 2010; Ojala and Tyrväinen, 2011a; Ries, 2011) have been developed mainly for practitioners, with the theoretical underpinnings of the concept remaining unformed (Hedman and Kalling, 2003; Zott et al., 2011).

In filling these gaps, the aim will be to integrate insights from opportunity creation theory (Alvarez and Barney, 2007, 2010; Alvarez et al., 2013) with notions from business model literature. In the field of entrepreneurship, opportunity creation theory has been applied to the ways in which entrepreneurs create and subsequently develop their business under conditions of uncertainty. However, opportunity creation theory has not been adequately conceptualized in the literature of business model creation and development (cf. Ardichvili et al., 2003; Chesbrough, 2010). An examination of how software entrepreneurs create and develop their business models in conditions of uncertainty thus has the potential to contribute to both IS and business model literature.

As its main contribution, this paper presents a preliminary theoretical model explaining (i) how IT entrepreneurs create a business model on the basis of an opportunity, and (ii) how and why the business model evolves over time. In addition, the aim is to develop practitioner literature (Blank, 2013; Osterwalder and Pigneur, 2010; Ries, 2011) so that it includes theory while also contributing to the literature on technological evolution (Adomavicius et al., 2007, 2008; Arthur, 2009). In pursuing this aim, notions on the evolution of business models are incorporated. Readers may 
also note that the present paper expands and refines (both theoretically and temporally) previous studies by Ojala and Tyrväinen (2011a, 2011b).

The paper is organized as follows: it first discusses the theoretical background on business models and opportunity creation. Thereafter it presents the research methods, the case study findings, and the results of the analysis. Finally, a preliminary theoretical model is presented, leading to some concluding thoughts and practical implications.

\section{Business Models}

There has been a rapid increase in research on business models over the last two decades (Zott et al., 2011). However, in both IS and business literature, the term "business model" has tended to be loosely defined (Hedman and Kalling, 2003; Burkhart et al., 2011; Porter, 2001; Zott et al., 2011). In an extensive review, Zott et al. (2011) found that business models have often been studied without clear definitions of the concept applied. This makes the use of the term "business model" challenging both in academic literature and in practice. Very generally speaking, a business model can be regarded as a "story" that explains how a firm works (Magretta, 2002). However, as several studies on business models have suggested, a business model should be studied with reference to the firm's entire value network, making clear how value is created and delivered to customers and partners (Al-Debei and Avison, 2010; Osterwalder et al., 2005; Teece, 2010). Osterwalder et al. (2005) provide a comprehensive definition of their concept of a business model. They define a business model as "a description of the value a company offers to one or several segments of customers and of the architecture of the firm and its network of partners for creating, marketing, and delivering this value and relationship capital, to generate profitable and sustainable revenue streams" (Osterwalder et al., 2005, 10).

Using the definition provided by Osterwalder and coauthors (2005), and also recent literature on business models, this paper conceptualizes the business model as including four main components. These components are: (i) the product/service, (ii) the value network, (iii) value delivery, and (iv) the revenue model. These four components can be seen as simplified versions of the business model pillars presented by Osterwalder et al. (2005), and of the business model canvas presented by Osterwalder and Pigneur (2010). The aim in proceeding in this way was to facilitate 
the analysis, and to develop the theory. In other words, the endeavor here was not to give a "God's eye" view of reality, but rather to increase the theoretical understanding of social reality - something that is more achievable if one is able to simplify the phenomenon under study. Furthermore, the business model canvas (Osterwalder and Pigneur, 2010) situates a given business activity in the context of a given organization rather than in the context of an industry. In contrast, the business model schematic presented in this paper positions the business activity within the structure of the industry, including partners and end users.

The first component refers to a firm's product/service and its business logic. This involves how the product is related to other technologies in the market (Adomavicius et al., 2007, 2008; Arthur, 2009) and how it creates value for the various partners and customers included in the model (Al-Debei and Avison, 2010; Amit and Zott, 2001; Osterwalder et al., 2005; Osterwalder and Pigneur, 2010). The second component, that of the firm's network, refers to the key actors, such as partners and customers, within the firm's business model. Partners may provide a component or an infrastructure technology for the firm's technology, enabling or supporting its activities in the market (Adomavicius et al., 2008). According to Al-Debei and Avison (2010) a firm is dependent on the extent of the relationships that it maintains in its business model and indeed the relationships between a firm and its partners are commonly cited as an important component of a business model (Osterwalder et al., 2005; Osterwalder and Pigneur, 2010; Zott et al., 2011). The third component, value delivery, covers how value is delivered to the various partners and customers in the network. This aspect includes the notion that a business model should describe how a firm gets in touch with its customers (Osterwalder et al., 2005; Osterwalder and Pigneur, 2010) and how value is exchanged with the firm's partners (Al-Debei and Avison, 2010; Osterwalder and Pigneur, 2010; Teece, 2010). The fourth component, the revenue model, includes how a firm makes money - in other words, how the value that a firm offers to its end-users or network partners can generate financial revenue. One can see from the literature that the revenue model has a central role in many definitions of business models (Morris et al., 2005; Osterwalder et al., 2005; Osterwalder and Pigneur, 2010; Teece, 2010; Zott et al., 2011).

The notion of a business model may suggest a somewhat static description of a firm's activities; however, the model can continuously evolve. Hedman and Kalling (2003) emphasize that a business model should include a longitudinal process 
component, in order to cover the dynamics of the business model. In the field of IS in particular, there are constant changes in the technology and business environment, and these will impact on a firm's business model (Al-Debei and Avison, 2010; Teece, 2010). With regard to technological change, Adomavicius et al. (2008) have noted that when technologies evolve, some new technologies are introduced, and some existing technologies become extinct. Arthur (2009) has viewed the process as one of evolution; hence novel technologies tend to inherit elements from earlier technologies, and new technologies may in part be based on existing technologies. In seeking to understand the technological aspects, Adomavicius et al. (2008) divide technology into three different roles: (i) components, (ii) products, and (iii) infrastructure. The evolution of one of these technologies may impact on the development of the other technologies. Thus, Adomavicius et al. (2008) found that infrastructure technology may have either a supporting or an enabling role for product technologies, depending on the evolution of the ecosystem within which the product technology is applied. In other words, even when a fully-developed business model is successful, there is always the possibility that it will need to be modified or abandoned because of changing technologies or emerging competition (Teece, 2010). Osterwalder et al. (2005) suggest that a management team should analyze the current business model's correspondence with environmental changes, and that it should plan, change, and implement a new business model in line with these changes.

In a longitudinal case study on business model innovation, Sosna et al. (2010) found that the development of a business model was based on a trial-and-error learning process. The importance of learning and of continuous customer feedback has also been highlighted in the "lean startup" literature (Blank, 2013; Ries, 2011). The studies conducted have incorporated models encompassing how startups develop their product on the basis of customer feedback, and how they can "pivot," that is, change their business model, if the firm is not making progress. The aim of these models, given their practical orientation (Blank, 2013; Ries, 2011), has been to minimize the time used for product development, especially in the IT industry, in which the technology develops rapidly and in uncertain directions. However, the business model literature has not adequately explained how business models actually come into existence, nor how the components of a business model evolve in the course of a firm's actions and reactions in the market. To gain a better understanding of these aspects, the present study sought to integrate insights from opportunity 
creation theory; these would seem to have the potential produce a better understanding of business model creation and development as an overall process.

\section{Opportunity Creation Theory}

In the literature on entrepreneurship, opportunity creation theory (Alvarez and Barney, 2007, 2010; Alvarez et al., 2013) has been applied to situations in which entrepreneurs create and develop their business under conditions of uncertainty. The theory is based on the idea that reality is socially constructed, and that opportunities become meaningful when they are enacted as part of the social reality of entrepreneurs (Alvarez et al., 2013; Berger and Luckmann, 1967; Weick, 1979). Hence, there is no opportunity "waiting to be recognized"; instead, opportunities are created endogenously by the actions of entrepreneurs who are seeking to explore new products or services (Alvarez and Barney, 2007, 2010). Thus, an opportunity does not exist before an entrepreneur creates it through a process of enactment (Alvarez et al., 2013). This aspect distinguishes the theory from opportunity discovery theory, which regards opportunities as existing independently of entrepreneurs, and hence as objective phenomena, waiting to be identified and exploited (Alvarez and Barney, 2007; Kirzner, 1979, 1997). In other words, opportunity discovery focuses on active search behavior in which entrepreneurs are searching for new solutions for existing needs in the market (Ardichvili et al., 2003; Sarasvathy et al., 2003). By contrast, created opportunities are based on entrepreneurial perceptions, imagination, and social interaction (Alvarez and Barney, 2007; Sarasvathy, 2001). In opportunity discovery, there is knowledge of possible outcomes and their probability. Opportunity creation is more uncertain, since neither the possible outcomes nor their probability are known (Ardichvili et al., 2003). Because the present research focused on the ways in which IT entrepreneurs create and subsequently develop their business model under conditions of uncertainty, opportunity creation theory was used as a theoretical foundation for the study.

At the start of an opportunity creation process, an initial idea for creating an opportunity can be either "blind" or intentional in nature, bearing in mind that in many cases, early efforts have myopic characteristics (Alvarez et al., 2013). It often happens that an entrepreneur cannot see the end of the process from the beginning, due to the fact that opportunities cannot be observed or fully understood before they 
are enacted via a complex process of action and reaction in the market (Alvarez et al., 2013; Weick, 1979). In other words, an entrepreneur first creates an opportunity and then observes how customers and markets respond to the created product or service. There may turn out to be a mismatch between an entrepreneur's idea and objective reality, and/or the social constructions of customers (Alvarez et al., 2013; Weick, 1979). This will require reassessment of how the opportunity corresponds to the market, with efforts to "test" customers' perceptions (Alvarez and Barney, 2007; Sarasvathy, 2001, 2008). The process is highly uncertain, in so far as there is no current need in the market (Sarasvathy et al., 2003). For this reason, an entrepreneur may change the original idea dramatically after iterative actions and reactions, or even abandon the idea altogether (Alvarez and Barney, 2007). During the process, the opportunity evolves toward the needs in the market and also changes the beliefs and assumptions of entrepreneurs involved in the opportunity creation (Alvarez et al., 2013). The process may also include the involvement of other actors who can enable co-evolvement and co-enactment of the opportunity towards market demand (Alvarez et al., 2013; Sarasvathy, 2008). Sarasvathy (2001) noted that an entrepreneur creates the market for an opportunity by bringing together various actors who are interested in the opportunity.

In the literature on opportunity creation, little attention has been paid to the development of created opportunities. This is mainly because opportunity creation is seen as a longitudinal process in which the created opportunity develops continuously, in relation to changes in the market (Sarasvathy, 2008). Entrepreneurs develop created opportunities by considering the means available to them (abilities, knowledge, human resources, social networks, etc.), and they use these means to select a possible effect imagined by them (Sarasvathy, 2001). According to Sarasvathy $(2001,2008)$ there should be no fixed goal for opportunity development. Instead, opportunities should emerge during the development process, while entrepreneurs interact with the market. Here it should also be noted that opportunity development differs from product development, since opportunity development involves an entire firm, not merely one product (Ardichvili et al., 2003; Pavia, 1991).

In summary, the existing literature offers rich and comprehensive descriptions of business models. However, we do not know much about how software entrepreneurs create and develop their business models in a constantly changing environment, in which the development of new technologies is uncertain. Furthermore, there seem to 
be very few studies on how entire business models change over time, or on the factors initiating change. Research on entrepreneurship has provided a valuable theoretical framework to explain how entrepreneurs create new opportunities and develop their business ideas under uncertain market circumstances. Nevertheless, this literature has not been integrated into studies on business models in such a way as to explain how created opportunities lead to comprehensive business models. The aim of the study reported here was to integrate insights from opportunity creation theory into business model research, and to provide a realistic description of how software entrepreneurs create and develop their business model in an unstable market environment.

\section{Research Method}

It was recognized that the research method selected for a study of the type envisaged should make it possible to understand social phenomena in their natural settings, enable an in-depth investigation of complex phenomena, and capture cause-and-effect relationships. Based on these considerations, a case study method was selected (Darke et al., 1998; Pettigrew, 1990; Yin, 2009). The single-case method is useful in providing detailed (Edmondson and McManus, 2007) and empirically rich data (Eisenhardt and Graebner, 2007) connected to a phenomenon. A case study also facilitates an examination of changes within a firm and its environment (Eisenhardt, 1989; Pettigrew, 1990). In addition, there has been a call for more case studies to examine business models in general (Hedman and Kalling, 2003).

\section{Data collection}

The case firm for this study was selected for theoretical reasons, as advised by Eisenhardt (1989). The selected firm complied with the following criteria: (i) the firm used opportunity creation in its innovation process, (ii) the firm had a relatively long history, thus making it possible to observe changes in its business model, (iii) the firm was acting in a market segment in which rapid technological development and extensive changes were observable, (iv) the firm was relatively small, making it easier to observe entrepreneurial actions. The data collection for this study incorporated several types of empirical material covering the entire history of the case firm (see Table 1), from 2000 to 2014. The interviews with the employees of the firm took 
place in 2005, 2010, 2011, 2012, 2013, and 2014. The author conducted all the interviews for the study. The first two interviews focused on the initial business model and international growth of the firm ${ }^{1}$, whereas later interviews and investigations were mainly related to the development of the business model. Because the case firm was relatively small, interviews with the entrepreneur (referred to hereafter as the founder/CEO) who established the firm were the main source of information. However, to avoid bias from individual opinions (Huber and Power, 1985), nine other employees with a variety of positions in the firm were interviewed; thus different organizational levels were addressed, ranging from the Software Developer to the Chairman of the Board. Furthermore, three employees of the main partner were interviewed (see Table 1).

Altogether, 19 interviews were conducted for this study, with each interview lasting 45-90 minutes. All the interviews were recorded and transcribed verbatim, using a word processing program. Thereafter, the complete transcripts were sent back to the interviewees for review. For the most part the interviewees accepted the transcripts in the form in which they were sent. However, in some cases, the interviewees gave minor comments related to the misspelling of a partner's name or to some particular wording. In addition to the face-to-face ${ }^{2}$ interviews, telephone and e-mail communication was used to collect further information, and to clarify inconsistent issues if necessary. These communications were also added to the casestudy database. To avoid retrospective bias (Huber and Power, 1985; Miller et al., 1997), several different types of early records were used to validate the data whenever possible. These early records included the firm's private placement memo from the year of its establishment, together with press releases from the firm's early days. The interview data were compared with early records. If there were inconsistencies, these were discussed with the persons interviewed. In addition, if an interviewee was unsure about an important event, he/she was asked to check his/her e-mails to recall how the events progressed. This procedure worked well, as all the interviewees had saved past e-mails.

To ensure the accuracy of the business models, the firm's CEO validated these afterwards. The author gave the CEO access to the diagrams he had drawn to

\footnotetext{
${ }^{1}$ The results related to international growth have been reported in studies by Ojala and Tyrväinen (2006) and by Ojala (2008, 2009).

${ }^{2}$ All the interviews were conducted as face-to-face interviews apart from one interview which was conducted via Skype because of difficulties in finding a time for the face-to-face interview.
} 
represent the business models; thereafter the author discussed the diagrams with him, making some minor changes based the CEO's comments and on a common understanding. In the data collection, in addition to the actual interviews, many types of secondary information covering the entire history of the firm were used (Table 1), making it possible to form an extensive and detailed historical description of the firm, its business model, and the changes in the model. Using the secondary information, it was also possible to triangulate the information (Miles and Huberman, 1994), through comparison of the interview data with other information gathered on the case firm.

Table 1. Empirical material used in this study

\begin{tabular}{|c|c|c|}
\hline Data source & $\begin{array}{l}\text { Number of } \\
\text { interviews (or } \\
\text { other data sources) }\end{array}$ & $\begin{array}{l}\text { Year(s) + Number of observation(s)/ } \\
\text { title of interviewee }\end{array}$ \\
\hline Interviews with the CEO & 7 & $\begin{array}{l}2005(\mathrm{~N}=1), 2010(\mathrm{~N}=2), 2011(\mathrm{~N}=1), \\
2012(\mathrm{~N}=1), 2013(\mathrm{~N}=1), 2014(\mathrm{~N}=1)\end{array}$ \\
\hline $\begin{array}{l}\text { Interviews with various other } \\
\text { employees }\end{array}$ & 9 & $\begin{array}{l}2005 \text { (CEO of Japanese operations) } \\
2010 \text { (Vice President - software } \\
\text { engineering; Software Developer; } \\
\text { Chairman - board of directors; } \\
\text { Executive Director - corporate } \\
\text { planning; General Manager - technical } \\
\text { development) } \\
2013 \text { (Previous CEO; Financial } \\
\text { Controller; General Manager - } \\
\text { technical division) }\end{array}$ \\
\hline $\begin{array}{l}\text { Interviews with the employees of } \\
\text { the main partner in Japan }\end{array}$ & 3 & $\begin{array}{l}2010 \text { (General Manager - global } \\
\text { management) } \\
2013 \text { (General Manager - business and } \\
\text { legal affairs; Executive Director - home } \\
\text { entertainment group) }\end{array}$ \\
\hline Press releases & 50 & $\begin{array}{l}2002(\mathrm{~N}=1), 2003(\mathrm{~N}=1), 2004(\mathrm{~N}=4), \\
2005(\mathrm{~N}=15), 2006(\mathrm{~N}=5), 2008(\mathrm{~N}=2), \\
2010(\mathrm{~N}=1), 2011(\mathrm{~N}=2), 2012(\mathrm{~N}=8), \\
2013(\mathrm{~N}=11)\end{array}$ \\
\hline Brochures & 5 & $2009(\mathrm{~N}=1), 2010(\mathrm{~N}=1), 2013(\mathrm{~N}=3)$ \\
\hline Web-sites & 1 & $2005-2013$ \\
\hline Private placement memo & 1 & 2000 \\
\hline Video advertising material & 3 & $2013(\mathrm{~N}=3)$ \\
\hline
\end{tabular}

\section{Data analysis}

Content analysis was applied in the data coding (see Appendix 1). The author conducted the analysis in line with the recommendations of Miles and Huberman (1994). The analysis of the case data consisted of three parallel activities: (i) data reduction, (ii) data display, and (iii) conclusion-drawing/verification. In the data reduction phase, the complete transcripts from all the interviews were simplified and 
summarized by compiling a detailed document covering the history of the case firm. In addition, information from other materials (secondary data) was added to the written document. Thereafter, the data were divided into the following categories as they appeared in the document: (i) business model creation and the first business model (1999-2000), (ii) the second business model (2001-2005), (iii) the third business model (2006-2010), and (iv) the fourth business model (2011-2014). This follows the guidelines by Pettigrew (1990), who argued that arranging incoherent aspects in chronological order is essential in understanding the causal links between different events.

In the data display phase, the most important data drawn from the categories were arranged in tables and figures. These tables included quotes from the interview data illustrating the important events in the case firm's history. The most relevant quotes from the interviews are included later in this paper. The figures created in this phase visualize the business models used by the case firms (Figures 1-4). The figures are based on the business model components defined in the literature review section, and they demonstrate the product, the value network, value delivery, and the revenue model. However, it must be borne in mind that the figures represent simplified views of reality, and that each model is explained in more detail in the accompanying text. The figures also respond to the call by Osterwalder and Pigneur (2013) for better visualization of business models.

The phase of conclusion drawing and verification concentrated on identifying the aspects that appeared to have significance for this study. In this phase, the regularities, patterns, explanations, and causalities related to the phenomena were noted. Finally, data from the case history of the firm, together with the considerations presented in the literature review, were applied with a view to creating a preliminary theory of business model creation and development.

\section{Background of the Case Firm}

The case firm, G-cluster, develops interactive cloud gaming platforms and games-ondemand services. The business concept of G-cluster was based on what was (in 2000) an entirely new way to provide PC and console games to players. Traditionally, games are installed on a computer or a game console, which runs the game. In the Gcluster business model, by contrast, games are run on a cloud platform. The platform 
is operated by the game servers that transmit the game content as an MPEG stream to the devices of end-users, over the broadband network. The client devices receive the stream, display the game, and transmit users' commands back to the game servers. Thus, G-cluster's gaming platform makes it possible to bring games to the cloud environment. G-cluster was established in Finland in 2000. Currently G-cluster has its headquarters in Japan, its $R \& D$ activities in Finland, its sales and marketing subsidiary in the USA, and its content acquisition activities in France.

\section{Business model creation and the first business model}

At the end of 1999, Erik, founder/CEO of G-cluster met his brother's childhood friend, Juhani ${ }^{3}$. Erik's background was in a software company that developed videoconferencing equipment and related software for PCs. Juhani's background was in a technology firm that developed physics simulations for game publishers. However, after selling his firm he started to work as a "business angel" for start-ups. The idea for the new product and firm was created by Erik and Juhani in collaboration. They were aware that telecom operators were at that time planning to launch third generation $(3 \mathrm{G})$ networks and that mobile phone manufacturers were developing new mobile phones with better screen resolution for these networks. Erik and Juhani realized that the computing power and memory capacities of mobile phones would still be relatively low and that there would be several models of mobile phones using different operating systems. In addition, the life cycle of mobile phones was becoming very short, with new models appearing in the market approximately every six months. All these factors made it difficult to develop good content for mobile phones. The founder/CEO explained this as follows:

"We started to think that this [software development for mobile phones] should somehow be done differently, especially for games, since games are challenging. So we thought that if we could start to run games, we could start to run all the other applications as well."

\footnotetext{
3 "Juhani" is a pseudonym.
} 
To meet this challenge, Erik and Juhani had the idea of developing a game platform that would make it possible to send game content to mobile phones over the $3 \mathrm{G}$ network from a central computer, and players' game commands back to the central computer operating the game. The founder/CEO described the market situation in the following way:

"We thought that instead of running games on mobile phones, we could run the games on a server that would encode the gaming content in real time to an MPEG stream and send it to the mobile phone, which would recode and show the game. Thus, it would be enough if a mobile phone could encode and recode a bit-stream."

It also became clear, at the end of 1999, that the infrastructure technology needed for the platform would soon be ready for the idea, since $3 \mathrm{G}$ permits were being granted to network operators and the first mobile phones with color screens were coming onto the market. However, there were many uncertainties related to the infrastructure technology. For instance, there was no information on the true speed of data transfer in $3 \mathrm{G}$ networks, or on what the cost of data transfer would be for the consumer. The founder/CEO explained this as follows:

"There were so many open questions related to the technology and how it would develop in the future. Would there be $3 G$ networks? What would the cost of data transfer be? Would there be enough broadband capacity available in mobile networks? Would the screen resolution of mobile phones be good enough?"

The previous $\mathrm{CEO}^{4}$ described the situation as follows:

"There was a huge amount of hype regarding $3 G$ networks... Mobile phone manufacturers talked about nothing but how $3 G$ was coming and how it would impact on the whole telecom sector. It seemed clear that within a year $3 G$ networks would be fast enough to play games.",

\footnotetext{
${ }^{4}$ The previous CEO refers here to a person who worked in G-cluster between 2000 and 2002 as CEO, before the founder took over as CEO. During 2000-2002 the founder (and current CEO) worked as CTO in G-cluster, and was also involved in all the important decisions related to business development and the business model.
} 
The first business model of the firm is shown in Figure 1. In this model, G-cluster connected content providers (game publishers ${ }^{5}$ ) with telecom operators by providing a platform that could be used to deliver games over the wireless network. The idea was that G-cluster would license game content from content providers (mainly game publishers and other firms developing video or mobile games). Thereafter, G-cluster would port ${ }^{6}$ the licensed source code of the game into binary code so that G-cluster could run the game on its platform, operated by telecommunication operators with $3 \mathrm{G}$ networks. The next stage would be for telecommunication operators to encode the gaming content in real time to an MPEG stream and to send it to end-user devices that would decode the MPEG stream. End users would be able to play games via mobile phones, or via other wireless devices such as PDAs (personal digital assistants) connected to the $3 \mathrm{G}$ network. The model was to be based on revenue sharing between the partners.

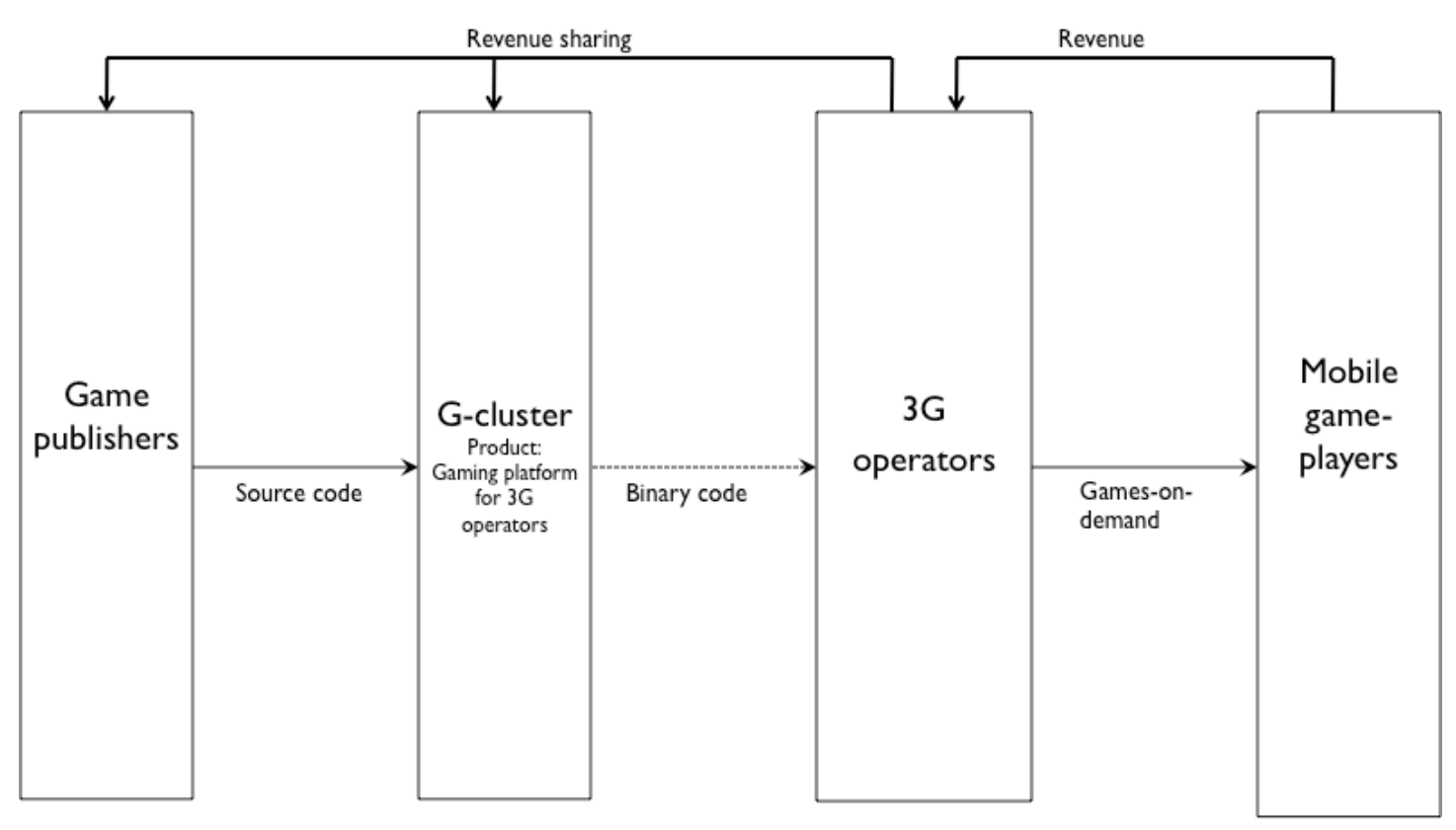

Figure 1. The first business model, 2000

Nevertheless, Erik and Juhani fairly quickly realized that the preconceptions regarding the infrastructure technology - i.e. $3 \mathrm{G}$ networks and their capacity - were far too optimistic. The development of $3 \mathrm{G}$ networks was not as fast as predicted at the

\footnotetext{
${ }^{5}$ Game publishers work as third-party application providers that offer games as applications to endusers of the platform (Ghazawneh and Henfridsson, 2013).

${ }^{6}$ Port refers to the process by which software (or a game) written for a specific platform/operating system is moved to another platform/operation system.
} 
start of 2000 , and the $3 \mathrm{G}$ network was not reliable enough to handle the real-time bitstream without latency. In addition, the first $3 \mathrm{G}$ mobile phones were very expensive for the average user. Hence, they had to find an alternative way to bring the product to the market, involving changes in the business model. The previous CEO explained the situation as follows:

"We realized it [the fact that $3 G$ networks would not be fast enough] quite soon. I thought, OK, we need to change the strategy and find an alternative way. We still believed in the original idea... and we understood that there were also other types of networks available."

\section{Development of the second business model}

In 2001, G-cluster started to look for alternative infrastructure technologies for their platform. One possibility was to develop their platform for the markets provided by Internet Protocol Televisions (IPTVs). This opportunity was based on the fact that the gaming platform that had been developed for $3 \mathrm{G}$ networks would work also in fixed networks. However, they soon realized that the IPTV market was still undeveloped, and that they could not reach enough customers to make the business profitable. Thus, G-cluster started to offer games-on-demand services for PC users over the Internet, in addition to the small number of IPTV operators they worked with. The second business model is shown in Figure $2^{7}$.

\footnotetext{
${ }^{7}$ In reality, there were several smaller changes in the business models; thus, the business model figures shown here illustrate only the major transitions in the models.
} 


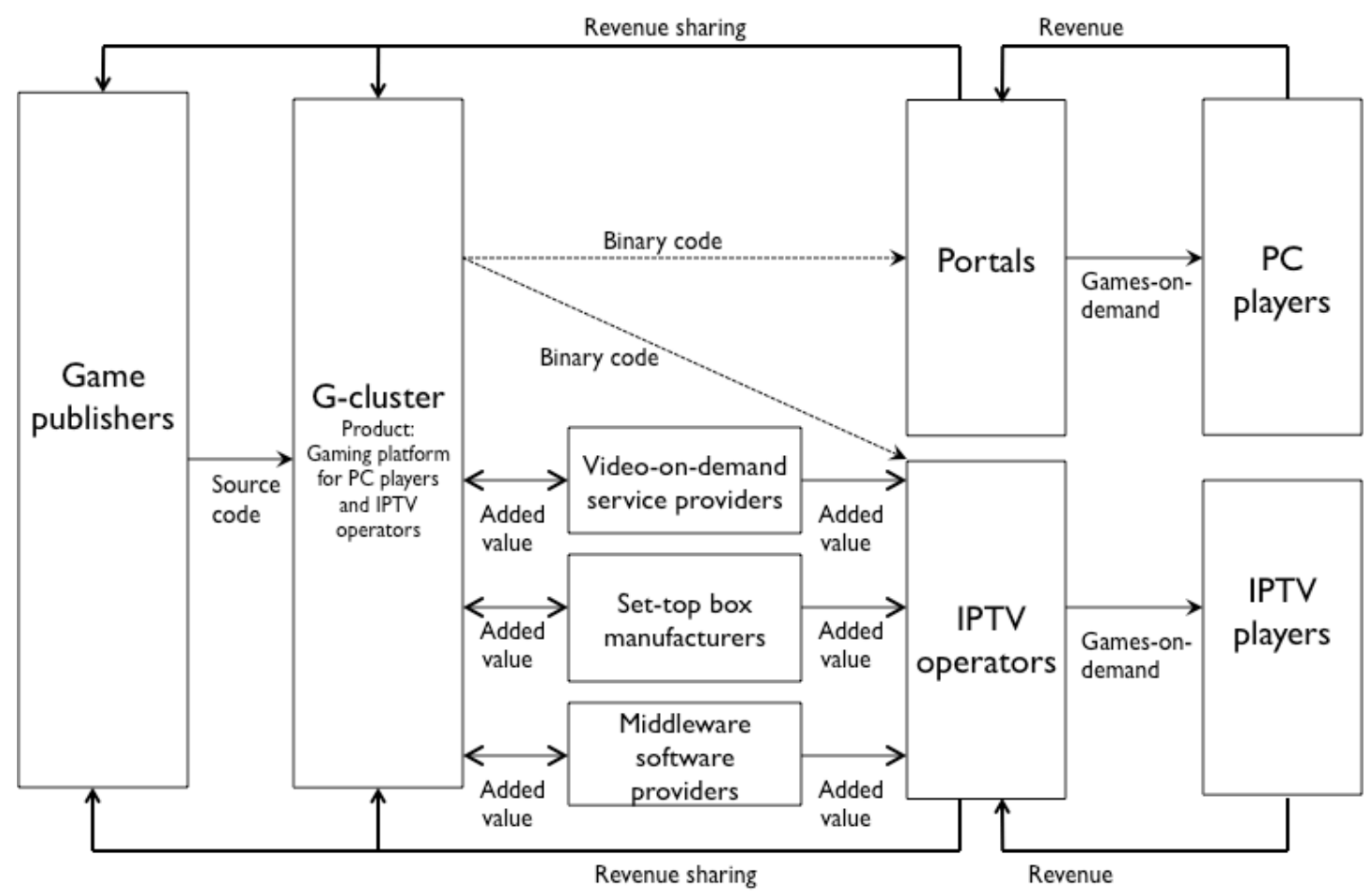

Figure 2. The second business model, 2005

The basic idea in this business model was the same as in the original one. However, in this new model G-cluster used portals and IPTV operators as sales channels to endusers. The model involved challenges, as it was difficult for such a small firm to have a contract with large telecom operators providing IPTV services, or to acquire game content for its platform from game publishers. The global economic situation was also difficult at the time (early 2000) and this affected G-cluster's business. The firm was unable to make up-front investments, but the idea of revenue sharing with partners proved successful. In this revenue model, the income was shared among the portals, IPTV operators, G-cluster, and game licensors. In practice, this was implemented in such a way that the portals and IPTV operators charged the end-users (players) and then divided the income between the partners. The previous CEO explained the situation as it was in these early days:

"It [revenue sharing] was clear to us from the beginning. It was a way to share the risks and profits evenly with partners. And it was not possible for us to offer any upfront investments because of the difficult financial situation we had initially.'

He added: 
"It is worth remembering that it was a very challenging time to do any business, at the start of 2000. We were continually looking for successful pilot projects, credible partners, and funding... It was the time after the IT bubble and all the investors were leaving the market. Once, I had a meeting with a venture capital firm but the firm was about to go bankrupt. We did go to the meeting but there were removal boxes waiting because they were closing their office."

Because of the uncertainty regarding income, G-cluster had to demonstrate other benefits that would bring value to the game publishers if they started to use Gcluster's gaming platform. These benefits included, for instance, (i) avoiding illegal copying, (ii) avoiding second-hand markets, (iii) a more durable market for games, and (iv) flexible revenue models. In G-cluster's business model, illegal copying became impossible. This was due to the cloud technology used, which allowed the game to be run in the cloud and streamed to end-users. Thus, the end-users never got any game code that could be copied. Illegal copying was a major problem in games markets, and finding ways of avoiding this problem motivated game publishers. Virtual delivery also helped to cut down second-hand markets, which would be beyond the reach of game publishers. Because shelf space was almost free in Gcluster's virtual store, games could be made available to the end-user for a longer time. This differed from traditional games stores in which the time frame for new games was relatively short and subject to intense competition. Virtual game delivery made possible a variety of revenue models, such as renting the game for a certain time period, or packaging a number of games into an attractive collection. Finally, after negotiations with several game publishers, including demonstrations of the benefits of the platform, G-cluster was able to license the source code and port it to their platform.

In addition to game content, G-cluster needed IPTV operators with servers on which the G-cluster platform could be operated. For this purpose it was necessary to find network operators who had a broadband network with the IPTV feature, as it was important to have rapid two-way data transfer. Here one can see that broadband capacity played an important role as an enabling technology for G-cluster's platform. Network operators were observed to have good marketing channels and a pre-existing customer base. Furthermore, the IPTV operators offered a well-known brand that 
could be used for marketing purposes. In some cases, the operators also motivated game publishers to make their games available for G-cluster's platform. These factors were all important to G-cluster, since the network operators made available resources that G-cluster could not acquire otherwise. However, the move towards cooperation with large companies such as IPTV operators was not easy. G-cluster needed to demonstrate the value of its product to network operators. In addition to monetary benefits, the G-cluster service offered a good opportunity to extend the network operators' existing product portfolio. By using G-cluster's game platform, network operators with IPTV capability had more content to offer their customers, and were able to differentiate their offering from that of competitors. The founder/CEO commented on this as follows:

"Globally, most of the operators are in a market situation where they send a letter to customers saying that they have doubled the connection speed of the broadband network, and decreased the price of the connection. So, in this kind of situation it is difficult to increase revenue. However, value-adding services such as video-ondemand and our games-on-demand services are one way to increase the offering and the revenue."

To get into the market and achieve cooperation with IPTV operators, G-cluster needed help from other firms. These firms were (i) video-on-demand service providers, (ii) set-top box manufacturers, and (iii) middleware software providers. For video-on-demand service providers, G-cluster's gaming platform made possible a new feature that did not compete with their existing services, but which allowed them to offer more content for network operators. In-line, set-top box manufacturers needed new functions for their devices (which they could introduce to network operators) and G-cluster's platform brought extra value for them. Middleware software providers who sold software to IPTV operators benefited from G-cluster's platform, as they were able to show that in addition to video-on-demand and other TV channel services, their software could also handle games-on-demand services. The cooperation among these three different types of firms was based mainly on various non-monetary mutual benefits. The founder/CEO explained the situation as follows: 
"For us it was quite an easy situation. We made contacts with all possible firms who could benefit from our product and we found many firms who were willing to enter into cooperation with us... because our product was so unique. So there were no corresponding products in the market."

These firms already had relationships with IPTV operators; thus they were able to provide added value for G-cluster by helping them to achieve a contract with the key decision-makers among the operators. In addition, by cooperating with video-ondemand service providers, G-cluster gained an invoicing system for their service as a component technology ${ }^{8}$. The founder/CEO explained this:

"Video-on-demand service providers have to provide some kind of integration of their invoicing system for network operators. We liked the fact that the payment would be easy [for the end-users], meaning that it was useful if all the services were included in the same invoice from the network operator. Thus, we had corresponding requirements in integrating the invoicing system for our games service."

The MPEG streaming technology used by the IPTV operators also enabled delivery of the games to PC users. In 2005, G-cluster had its own game servers in Japan, and it used Internet portals to deliver the game content to PC users. By logging onto a portal's website, PC players were able to select the games. The portals handled the marketing activities and the charging of customers. For the portals, adding Gcluster's service was an easy way to gain extra revenue: they did not have to make specific investments, since the gaming service was easily integrated with their existing business. The founder/CEO highlighted this as follows:

"For the portals, it was very easy to integrate our service with their own without any additional investment. They just needed to add a link to their website, and the link gave access to our service."

${ }^{8}$ In-line with Adomavicius et al. $(2007,2008)$, component technology refers here to technologies that form subunits or subsystems to other technologies (see also the Business Models section). 


\section{Development of the third business model}

Figure 3 demonstrates the business model of G-cluster in 2010. It shows that several important changes had occurred over a five-year period. These were a consequence of changes in the market environment and in G-cluster's product. First of all, G-cluster now focused solely on IPTV users. They had abandoned PC markets because of increasing competition and the fact that simpler PC games had increasingly become free to the players. The situation was now such that those players who did wish to play high-end games tended to buy games from a game store, and they were willing to invest in games consoles and related equipment. In any case, network operators had greatly increased their IPTV offering during the five-year period, and the customer base with reliable IPTV connections was growing rapidly.

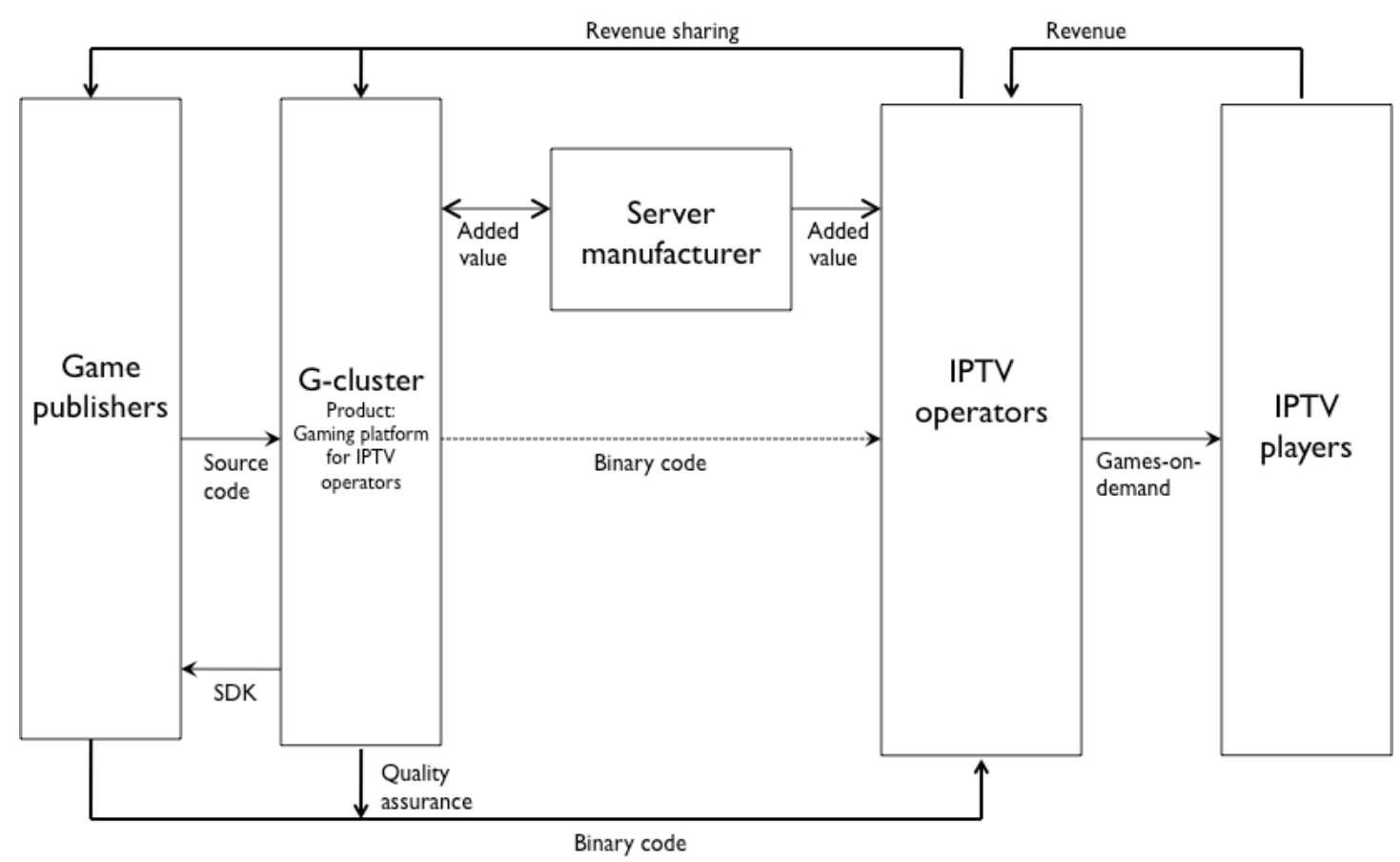

Figure 3. The third business model, 2010

As a second aspect, G-cluster focused on product development by integrating component technology with its platform - a technology that had previously been provided by its partners. Consequently, they became less dependent on third parties and were able to offer a ready-made product for the IPTV operators. G-cluster also started to provide its own software development kit (SDK) to game publishers, allowing the game developers to code their games directly for G-cluster's platform. 
This enabled rapid publication of the games and involved savings in G-cluster's resources, as there was no need to port a licensed source code into the binary code required by the platform. In these cases, G-cluster merely provided quality assurance for the games coded by the game developers. The founder/CEO described the situation as follows:

"Now we have an SDK for game developers. They can make games directly for our platform, so we can deliver them directly to IPTV operators... Previously we ported all the games we licensed for the platform... it took a lot of time and effort."

The vice president of software engineering explained this as follows:

"Previously we only gave tools to IPTV operators that they could use when they integrated our system with their web-based system... Now we have integrated the whole portal to our product, so it is much easier to sell, as there is much less integration work for operators."

As a result, the benefits previously provided by video-on-demand service providers, set-top box manufacturers, middleware software providers, and portals became less important, and these firms were removed from the business model. The development of the product made it easier to access IPTV operators without the need for several partners. The marketing efforts over a period of five years also helped Gcluster in making direct contact with the network operators. At the same time, portals were excluded from the business model because of the change from PC users to IPTV users.

In 2010, G-cluster established a cooperation agreement with a large and wellknown server manufacturer. Although there were no actual business activities (i.e. no buyer-customer relationship) between the firms, the collaboration provided mutual benefits for both firms. Compared to earlier partners, this collaboration brought a more reliable and influential partner, facilitating negotiations with new IPTV operators. Because the server manufacturer was conducting business with network operators around the world, the cooperation increased G-cluster's marketing and sales resources. It also made it easier to find the right contact people from the customer side, and added credibility to its business negotiations. Conversely, the server 
manufacturer obtained added value by integrating G-cluster's technology within its servers. This offered a new feature that the server manufacturer was able to use in marketing its servers to IPTV operators. According to the founder/CEO:

"Our product is highly beneficial to firms that sell servers to network operators. They can tell the network operators that by making a small additional investment, they can get an infrastructure that can be used to deliver our games-on-demand services."

\section{Development of the fourth business model}

Because the business model in 2010 was limited only to the infrastructure technology provided by IPTV operators, the market coverage in the gaming markets remained relatively small. To expand its market coverage, G-cluster brought a cloud game console, the "G-cluster gaming machine" to the market in 2013. The console was a small physical device that enabled end-users to gain access to G-cluster's game server without having an IPTV connection. Thus, the console worked over any wireless network if the broadband connection was fast enough. This expanded G-cluster's customer base to players without IPTV services. Hence, the business model was no longer tied solely to IPTV providers. To enable marketing of the game console, Gcluster started to cooperate with network operators. However, IPTV operators still play an important role in G-cluster's business model, since IPTV operators have a large customer base, making it possible to reach a large number of end-users.

Another change in the business model was that there was no longer any cooperation with the server manufacturer (Figure 4). Because G-cluster now had wellknown IPTV operators as its reference customers, it did not need the service manufacturer or other third parties to reassure operators about its service. The previous CEO explained the present situation as follows:

"It is very interesting to see that after the fourteen years, the original idea is still alive and that it never died, even it was over ten years ahead of its time. And now it fits with current terminology such as 'cloud gaming' ... when we started there were no terms such as 'cloud,' we talked about server solutions." 


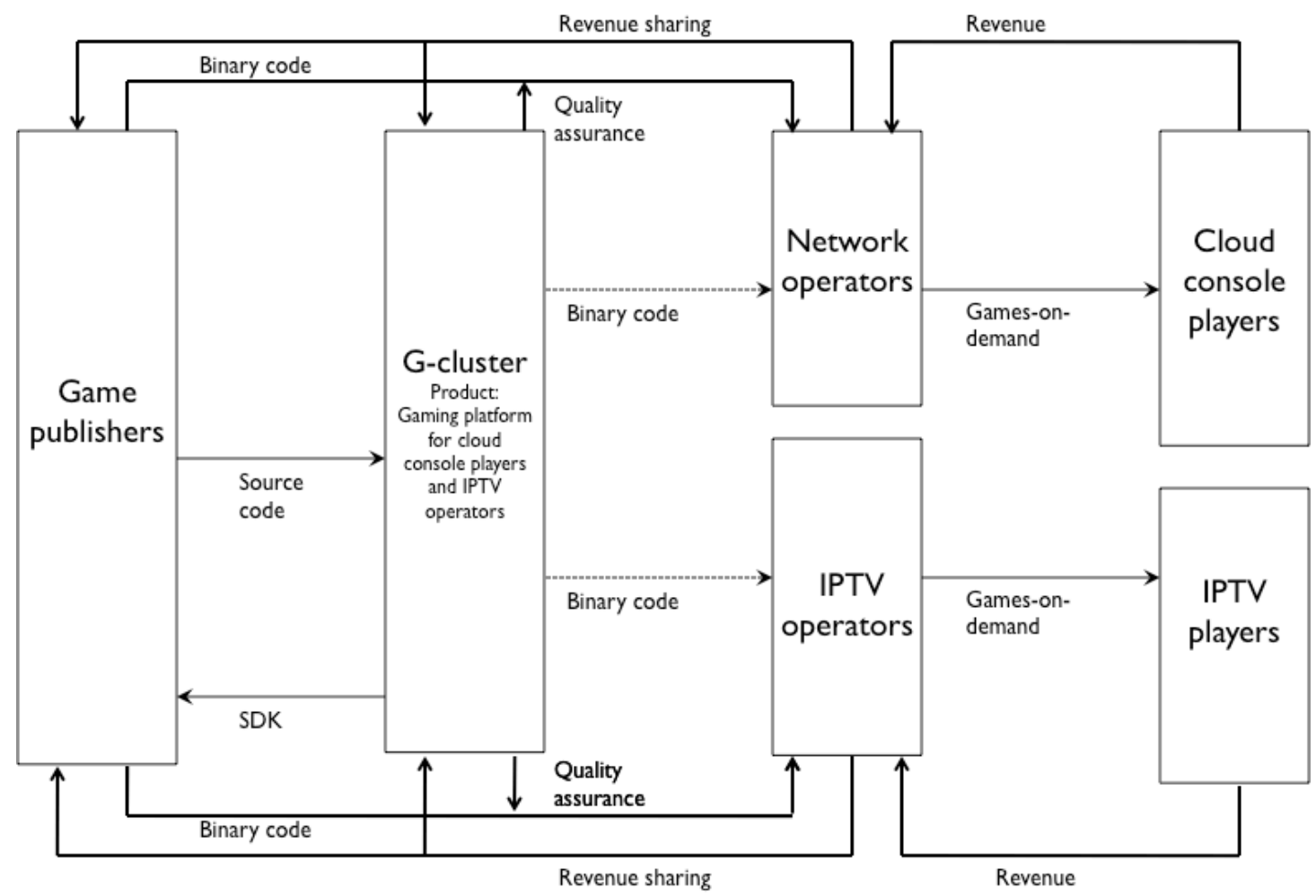

Figure 4. The fourth business model, 2014

\section{Toward a Theory of Business Model Creation and Evolution}

Using opportunity creation theory as a foundation, together with the empirical findings, and referring to previous literature on business models, it is possible to formulate a preliminary theory of business model creation and evolution. Figure 5 outlines the theory as including four phases: (i) business model creation, (ii) a business model, (iii) business model reassessment, (iv) business model development, and (v) business model abandonment. The three phases ii, iii, and iv form a cycle in which the business model evolves over the period in question. 


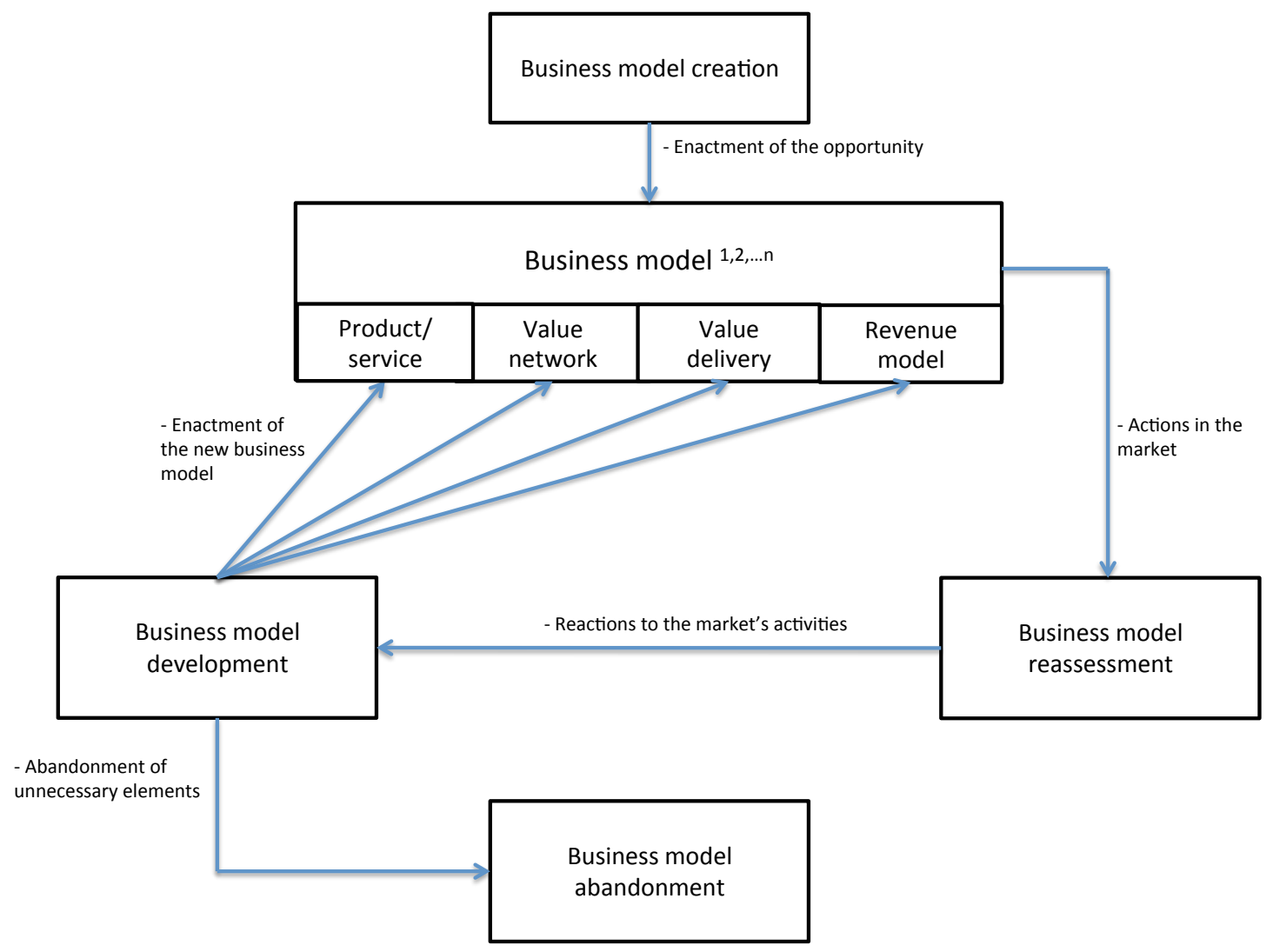

Figure 5. A preliminary theory of business model creation and evolution

In the business model creation phase, the created opportunity ${ }^{9}$ is based on entrepreneurs' perceptions and assumptions regarding how technological development might produce new IT-based business opportunities (cf. Alvarez and Barney, 2007; Sarasvathy, 2001; Sarasvathy et al., 2003). This phase is firmly based on an entrepreneur's abilities, imagination, knowledge, and social networks (cf. Sarasvathy, 2001, 2008). As the case findings demonstrate, the co-founders of the case firm used their knowledge and imagination to create a new game platform. They started to work on the opportunity, even though the market for the product did not yet exist and the infrastructure technology that would enable use of the platform was still under development. However, the entrepreneurs strongly believed that the created opportunity might be used in such a way as to overcome the limitations of existing

\footnotetext{
${ }^{9}$ In the context of this study, opportunity creation refers to the creation of new markets for a product or service through an enactment process (conjoined with imagination and market interaction) at a point in time when there is no pre-existing demand. This created opportunity is manifested via a business model within the emerging markets.
} 
technology. This is in line with Sarasvathy et al.'s (2003) notion that created opportunities arise in a context of uncertainty - a situation in which a demand does not exist, and in which the future is unknowable. This business model creation phase occurs before any operational business, and through the enactment process it leads to the first business model.

The business model is an outcome of the business model creation or the business model development phase, and it encompasses the product/service, value network, value delivery, and the revenue model. In line with the model, the created opportunity is brought to the market and taken into commercial use, or at least brought to the point of a trial run. By acting in the market, a firm can experience how the created business model fits market needs. This makes it possible to identify the potential partners for the value network, to see how value can be delivered between the partners, and to determine the revenue model to be aimed at. The business model will allow the firm to see how the market reacts to the opportunity. However, it should be noted that the first model rarely works, since there are likely to be challenges related to the partners' assumptions or to customers' needs.

In pursuing the initial business model, the firm will experience how the created technology suits existing component, product, and infrastructure technologies in the market (cf. Adomavicius et al., 2007, 2008). As the case findings demonstrate, Gcluster's first business model was very simple. The firm thought of using games publishers as content providers, and $3 \mathrm{G}$ operators as a delivery channel to the endusers, namely mobile game players. However, this business model did not work out, due to the fact that the development of the infrastructure technology was slower than predicted. If there is discordance between the business model and the market expectations, or between the business model and technological requirements, this will lead to the business model reassessment phase.

In the business model reassessment phase, entrepreneurs evaluate different courses of action based on changes in technology, market conditions, and interaction with partners in the firm's network. This is in line with the more general arguments of Alvarez and Barney (2007), to the effect that entrepreneurs observe how customers and markets are developing, and envisage certain possibilities based on the changes noted. In the case firm, the entrepreneurs realized that the infrastructure technology provided by $3 \mathrm{G}$ networks would not be fast enough for their product and that they would have to readjust their strategy. This demonstrates how entrepreneurs have to 
find constructive ways to address market needs and technological limitations; in so doing, they must seek out suitable value networks and technologies that will allow them to take the opportunity further. On this basis, a firm can start to develop the components of its business model further. This leads to the business model development phase.

In the business model development phase, the business model is developed further, in accordance with market phenomena, such as changed market conditions and/or technology. This may require additional development of the product to match technological evolution, with changes in market strategy, or segmentation of the product. Furthermore, there may be a need to find new partners or exclude existing partners from the value network, and to reconsider the value delivery and revenue model between the partners. In this phase, the business model evolves toward the prevailing needs in the market (cf. Alvarez et al., 2013). As the case findings demonstrate, the original idea for the game platform and for the product itself remained the same. Even if platform technology may enable rapid and large-scale adoption (Tilson et al., 2013), the case firm was dependent on the evolution of infrastructure technology, an aspect that had hitherto limited market penetration. The crucial point here was that G-cluster was able to use its knowledge and the partners available to it in order to take the idea further and into a new environment. This implies that the selection criteria for business model development should be based on the means available rather than on specific or well defined goals. More broadly, it underlines the uncertainty of the entire process (cf. Sarasvathy, 2001).

Through the enactment process, the business model development phase leads to a more refined business model that corresponds to current technological developments in the market and satisfies the needs of customers and partners. This cycle can continue until a firm finds a sustainable business model, or else abandons the model (or certain components of it). In other words, the opportunity development phase may lead to business model abandonment in which the whole model, or some components (e.g. technology or network partners) of the earlier business model, are removed as non-profitable or unfeasible.

A new business model may remain in a state of uncertainty, since the developed business model may fall below expectations, at which point the firm will have to rethink its subsequent actions (cf. Alvarez and Barney, 2007). As shown in Gcluster's second business model, the main target group, i.e. PC players, was not very 
profitable, due to fierce competition in the PC game markets. In addition, G-cluster was highly dependent on third parties who could provide supplementary component technology for its software. This led to a second reassessment phase, and development of the business model. Here one can see a progressive cycle operating between business model reassessment, business model development, and a new business model. Table 2 illustrates the various elements identified in the study, using examples from the case study.

Table 2. Illustrations of the different phases of the theoretical model

\begin{tabular}{|c|c|c|}
\hline Phases & Theoretical concepts & Empirical examples \\
\hline $\begin{array}{l}\text { Business model } \\
\text { creation }\end{array}$ & $\begin{array}{l}\text { - The entrepreneur's abilities, } \\
\text { knowledge, imagination, and } \\
\text { social networks } \\
\text { - Decision-making context } \\
\text { uncertain }\end{array}$ & $\begin{array}{l}\text { - Creation of something for forthcoming } \\
\text { 3G technology } \\
\text { - Limitations in existing technology } \\
\text { - Uncertainties in forthcoming } \\
\text { technology }\end{array}$ \\
\hline Business model & $\begin{array}{l}\text { - Enactment of the created } \\
\text { opportunity } \\
\text { - Formation of the components } \\
\text { of the business model } \\
\text { - Testing the reactions of the } \\
\text { market to the business model } \\
\text { created }\end{array}$ & $\begin{array}{l}\text { - Formation of the business model } \\
\text { components: } \\
\text { - Product: gaming platform for } 3 \mathrm{G} \\
\text { operators } \\
\text { - Value network: game publishers, } 3 \mathrm{G} \\
\text { operators, mobile game players } \\
\text { - Value delivery: sales channel for game } \\
\text { publishers, supplementary services for } \\
3 \mathrm{G} \text { operators } \\
\text { - Revenue model: revenue sharing } \\
\text { - Pilot tests for the platform }\end{array}$ \\
\hline $\begin{array}{l}\text { Business model } \\
\text { reassessment }\end{array}$ & $\begin{array}{l}\text { - Evaluation of different courses } \\
\text { of action based on market } \\
\text { reactions and technology } \\
\text { evolution }\end{array}$ & $\begin{array}{l}\text { - Development of the infrastructure }(3 \mathrm{G}) \\
\text { technology was slower than predicted } \\
\text { - Development of IPTV technology }\end{array}$ \\
\hline $\begin{array}{l}\text { Business model } \\
\text { development }\end{array}$ & $\begin{array}{l}\text { - Development of the business } \\
\text { model toward the prevailing } \\
\text { needs in the market, based on } \\
\text { the means available }\end{array}$ & $\begin{array}{l}\text { - Focus on alternative infrastructure } \\
\text { technologies } \\
\text {-Entry to IPTV and PC markets }\end{array}$ \\
\hline $\begin{array}{l}\text { Business model } \\
\text { abandonment }\end{array}$ & $\begin{array}{l}\text { - Abandonment of the } \\
\text { unnecessary components of the } \\
\text { business model }\end{array}$ & $\begin{array}{l}\text {-Abandonment of the platform for } 3 \mathrm{G} \\
\text { networks }\end{array}$ \\
\hline
\end{tabular}

\section{Conclusions}

\section{Theoretical implications}

This study contributes to IS and business model research in several ways. First of all, using opportunity creation theory as a foundation, it develops a preliminary theoretical model on business model creation and evolution. The model shows how 
business models can be created on the basis of entrepreneurial behavior, and how business models evolve further via business model reassessment and business model development. The model developed here has some connections with more practically oriented "lean startup" models by Ries (2011) and Blank (2013). In these models, feedback from the market, continuous development of the product, and the concept of a "pivot" have important roles. However, the models by Ries (2011) and Blank (2013) focus more on rapid and flexible product development, whereas the focus in this study was on the evolution of the entire business model. In other words, the model developed here sheds light on the importance of the value network, value delivery, and the revenue model, in addition to the product itself. Furthermore, the change aspect of a business model - i.e. the "pivot" identified by Ries (2011) - is here supported and developed through theoretical insights from opportunity creation theory. Altogether, this study gives support to and theoretically extends studies which had a practical orientation.

Secondly, this study incorporates theoretical insights from the field of entrepreneurship, applying these to the business model and to IS research. In so doing, it responds to the calls of a number of authors for more theoretically grounded studies on business models (Hedman and Kalling, 2003; Teece, 2010; Zott et al., 2011). However, this study does not merely incorporate relevant entrepreneurship theory in order to enrich and extend IS research; it also contributes to opportunity creation theory by conceptualizing the opportunity creation and development process in the context of a small software firm. The development of opportunities has largely been an unexplored area in opportunity creation theory, since the literature has mainly focused on the creation of the initial opportunity (Alvarez and Barney, 2007, 2010; Alvarez et al., 2013).

Thirdly, this study contributes to IS studies by demonstrating the interplay between technology evolution (Adomavicius et al., 2007, 2008; Arthur, 2009; Hanseth and Lyytinen, 2010; Henfridsson and Bygstad, 2013) and business model evolution, an aspect that has been poorly theorized in business model literature (Al-Debei and Avison, 2010; Hedman and Kalling, 2003). The findings here demonstrate how the different roles of technology (components, products, and infrastructure) introduced by Adomavicius et al. $(2007,2008)$ impact on business model evolution. In addition to the supporting and enabling roles of the infrastructure technology (Adomavicius et al., 2008), the findings here indicate that infrastructure technology may also have a 
constraining role for the development of product technology, and may thus retard the evolution of the business model. In line with Hanseth and Lyytinen (2010), it appears that the infrastructure may set limits on what can be designed and implemented at a given moment. However, this study demonstrates an additional way in which infrastructure technology can affect business model evolution, with entrepreneurs having to find alternative ways to bring the product to the market. This underlines the fact that technology can have several roles, and it demonstrates how essential it can be to learn from quickly-changing situations and to analyze new technologies (including both their opportunities and constraints) as they emerge (Ciborra, 1996). As noted by Henfridsson and Bygstad (2013), constricting infrastructures may foster creative processes which may lead to new ideas and innovations. The findings here build on this, suggesting that constricting infrastructures may also lead to new business models.

Fourthly, this study empirically examined a unique and understudied aspect of business models, involving creation, change, and development. The point here is that although recent literature on business models has revealed important components included in a business model (Osterwalder and Pigneur, 2010), and factors impacting on the development of the model (Blank, 2013; Ries, 2011) there has been lack of longitudinal studies investigating how and why business models change and evolve over time (Al-Debei and Avison, 2010; Hedman and Kalling, 2003; Teece, 2010). The present study demonstrates the ways in which a business model may evolve through reassessment and development phases - phases which operate as transition elements linking old and new business models. Here it should be noted that even though the study does not directly focus on "lean" product development, it gives some empirical support to the work of Blank (2013) and Ries (2011).

\section{Managerial implications}

From a practical point of view, the study has several implications for IT entrepreneurs. In line with the study by Blank (2013), the findings here illustrate and empirically validate the notion that a successful business does not always require a well-formulated business plan. Some business models develop via a trial-and-error process (Blank, 2013; Sosna et al., 2010), responding to changing conditions in the market. Since IT markets are rapidly changing, pre-defined business plans may not 
work and may have to be modified (cf. Ciborra, 1996). However, entrepreneurs do have to follow market developments closely and to reassess their business models if necessary. This underlines the importance of design as 'context making' (Ciborra and Lanzara, 1994), especially in the field of IT where technologies evolve rapidly and innovations do not always follow a linear or straightforward process.

Secondly, by expanding the ideas by Blank (2013) and Ries (2011), the findings here further demonstrate that in addition to product and customer development, entrepreneurs should consider possible changes in the value network and in value delivery. A business model should be built in such a way that it presents a valuable and low-risk means of expanding the business of network partners. By this means, entrepreneurs can acquire resources that are not otherwise attainable. In this study, by cooperating with partners, G-cluster gained both content for its service and marketing resources - resources that would not otherwise have been available for a small firm.

Thirdly, as proposed in supply chain literature (see e.g. Cachon \& Lariviere, 2005), revenue sharing between key actors may work well. In this case study, revenue sharing offered a good means of achieving low-cost market entry without huge upfront investments. The model also motivated all the partners in the business model to provide good services to the end-users who paid for the service. This appeared likely to work better than a model in which each service provider would have a customer-provider relationship with a different provider. In the latter case, service providers may be motived to pursue only their own advantages, rather than the advantages that can accrue through having an entire service delivered to the end-user.

Fourthly, in evaluating the success of G-cluster's business model, it can be observed that even if the business model progressed slowly, it attracted investments from several organizations, and well-known partners were found. G-cluster received funding from Broadmedia Corporation in 2005, SBI Investment in 2008, Intel Capital in 2011, SFR Development in 2012, NTT in 2013, and Orange in 2014. G-cluster's contracts with game publishers include many well-known brands, including Disney, Ubisoft, Warner Bros, Konami, and Electronic Arts. In addition, G-cluster currently has delivery contracts with Broadmedia, SFR, Orange, NTT, and FlarePlay. Overall, the study underlines the importance of patience when one is developing business models under conditions of uncertainty, bearing in mind that the evolution of infrastructure technology may set limitations on the development of product technology. 


\section{Limitations of the study}

There are several issues that should be considered in evaluating the findings of this study. Firstly, the research method used here made it possible to gain an in-depth view of the phenomenon. However, by its nature, the single-case study method requires caution as to generalization, bearing in mind the possibly context-specific nature of the findings. Furthermore, the data were collected and analyzed by a single author. This could raise concerns in terms of potential bias on the part of the author. To avoid this, the entire transcripts were sent back to the interviewees for review, and the firm's CEO validated the business models afterwards. Secondly, it has to be noted that only a small proportion of software firms create opportunities for markets that do not exist. Nevertheless, if they are successful in the opportunity creation process, they may become market leaders in their field of business, as one can see in the cases of Apple (Murugesan, 2011) and Starbucks (Sarasvathy, 2008; Schultz and Yang, 1997). Thirdly, it is difficult to say that how long a firm can be regarded as a start-up, or at what point it has moved onto a more mature business footing. If we use the definition by Blank (2012), to the effect that a start-up is a firm that searches for a repeatable and scalable business model, G-cluster was still in that process. However, even large and well-established firms can use opportunity creation to create new and more profitable business models (cf. Sarasvathy, 2008). Fourthly, the business models of the case firm are presented only for the years 2000, 2005, 2010, and 2014. These are the years that cover the main changes in the models, which include smaller, gradual changes over time. Not all the changes can be described here due to space limitations.

\section{Acknowledgements}

The author would like to thank William Baber, Sylvie Chetty, Brendan Gray, Eetu Luoma, Mikko Siponen, Pasi Tyrväinen, special issue guest editor Jonas Hedman, and the anonymous reviewers for their valuable comments and suggestions. Special thanks go to Erik Piehl, CEO of G-cluster, and to other employees who provided data for this study. Responsibility for the contents remains solely with the author. The research was partly carried out within the framework of the Digital Services research project financed by TEKES - the Finnish Founding Agency for Technology and Innovation. In addition, the Foundation for Economic Education in Finland 
(Liikesivistysrahasto) provided financial support for the research.

\section{References}

Adomavicius, G., Bockstedt, J.C., Gupta, A. \& Kauffman, R.J. (2007) Technology roles and paths of influence in an ecosystem model of technology evolution. Information Technology and Management, 8(2), 185-202.

Adomavicius, G., Bockstedt, J.C., Gupta, A. \& Kauffman, R.J. (2008) Making Sense of Technology Trends in the Information Technology Landscape: A Design Science Approach. MIS Quarterly, 32(4), 779-809.

Al-Debei, M.M. \& Avison, D. (2010) Developing a unified framework of the business model concept. European Journal of Information Systems, 19(3), 359-376.

Alvarez, S.A. \& Barney, J.B. (2007) Discovery and creation: alternative theories of entrepreneurial action. Strategic Entrepreneurship Journal, 1(1-2), 11-26.

Alvarez, S.A. \& Barney, J.B. (2010) Entrepreneurship and Epistemology: The Philosophical Underpinnings of the Study of Entrepreneurial Opportunities. The Academy of Management Annals, 4(1): 557-583.

Alvarez, S.A., Barney, J.B. \& Anderson, P. (2013) Forming and Exploiting Opportunities: The Implications of Discovery and Creation Processes for Entrepreneurial and Organizational Research. Organization Science, 24(1), 301317.

Amit, R. \& Zott, C. (2001) Value creation in E-business. Strategic Management Journal, 22(6-7), 493-520.

Ardichvili, A., Cardozo, R. \& Ray, S. (2003) A theory of entrepreneurial opportunity identification and development. Journal of Business Venturing, 18(1), 105-123.

Arthur, W.B. (2009) The Nature of technology: What it is and how it evolves. Penguin group, UK.

Berger, P. \& Luckmann, T. (1967) The Social Construction of Reality: A Treatise in the Sociology of Knowledge. The Penguin Press, UK.

Blank, S (2012) Search versus Execute. http://steveblank.com/2012/03/05/searchversus-execute/

Blank, S. (2013) Why the Lean Start-Up Changes Everything. Harvard Business Review, 91(5), 63-72. 
Burkhart, T., Krumeich, J., Werth, D. \& Loos, P. (2011) Analyzing the Business Model Concept - A Comprehensive Classification of Literature. ICIS 2011 Proceedings.

Cachon, G.P. \& Lariviere, M.A. (2005) Supply Chain Coordination with RevenueSharing Contracts: Strengths and Limitations. Management Science, 51(1), 3044.

Chesbrough, H. (2010) Business Model Innovation: Opportunities and Barriers. Long Range Planning, 43(2-3), 354-363.

Ciborra, C.U. (1996) The Platform Organization: Recombining Strategies, Structures, and Surprises. Organization Science, 7 (2), 103-118.

Ciborra, C.U. \& Lanzara, G.F. (1994) Formative contexts and information technology: Understanding the dynamics of innovation in organizations. Accounting Management and Information Technologies, 4 (2), 61-86.

Darke, P., Shanks, G. \& Broadbent, M. (1998) Successfully completing case study research: combining rigour, relevance and pragmatism. Information Systems Journal, 8(4), 273-289.

Eisenhardt, K.M. (1989) Building Theories from Case Study Research. Academy of Management Review, 14(4), 532-550.

Eisenhardt, K.M. \& Graebner, M.E. (2007) Theory building from cases: Opportunities and challenges. Academy of Management Journal, 50(1), 25-32.

Edmondson, A.C. \& McManus, S.E. (2007) Methodological fit in management field research. Academy of Management Review, 32(4), 1155-1179.

Ghazawneh, A. \& Henfridsson, O. (2013) Balancing platform control and external contribution in third-party development: the boundary resources model. Information Systems Journal, 23 (2), 173-192.

Hanseth, O. \& Lyytinen, K. (2010) Design theory for dynamic complexity in information infrastructures: the case of building internet. Journal of Information Technology, 25 (1), 1-19.

Hedman, J. \& Kalling, T. (2003) The business model concept: theoretical underpinnings and empirical illustrations. European Journal of Information Systems, 12(1), 49-59.

Henfridsson, O. \& Bygstad, B. (2013) The Generative Mechanisms of Digital Infrastructure Evolution. MIS Quarterly, 37 (3), 907-931. 
Huber, G.P. \& Power, D.J. (1985) Retrospective Reports of Strategic-level Managers: Guidelines for Increasing their Accuracy. Strategic Management Journal, 6, 171180.

Kirzner, I.M. (1979) Perception, Opportunity, and Profit: Studies in the Theory of Entrepreneurship. Chicago: University of Chicago Press.

Kirzner, I.M. (1997) Entrepreneurial Discovery and the Competitive Market Process: An Austrian Approach. Journal of Economic Literature, 35(1), 60-85.

Magretta, J. (2002) Why business model matter. Harvard Business Review, 80(5), 8693.

Miles, M.B. \& Huberman, A.M. (1994) Qualitative Data Analysis: An Expanded Sourcebook. California: Sage Publications.

Miller, C.C., Cardinal, L.B. \& Glick, W.H. (1997) Retrospective reports in organizational research: A reexamination of recent evidence. Academy of Management Journal 40(1), 189-204.

Morris, M., Schindehutte, M. \& Allen, J. (2005) The entrepreneur's business model: toward a unified perspective. Journal of Business Research, 58(6), 726-735.

Murugesan, S. (2011) What can we learn from Steve Jobs. IT-Professional 13(6), 6-8.

Ojala, A. (2008) Entry in a psychically distant market: Finnish small and mediumsized software firms in Japan. European Management Journal, 26(2), 135-144.

Ojala, A. (2009) Internationalization of knowledge-intensive SMEs: The role of network relationships in the entry to a psychically distant market. International Business Review, 18(1), 50-59.

Ojala, A. \& Tyrväinen, P. (2006) Business models and market entry mode choice of small software firms. Journal of International Entrepreneurship, 4(2-3), 69-81.

Ojala, A. \& Tyrväinen, P. (2011a) Developing Cloud Business Models: A Case Study on Cloud Gaming. IEEE Software, 28(4), 42-47.

Ojala, A. \& Tyrväinen, P. (2011b) Value networks in cloud computing. Journal of Business Strategy, 32(6), 40-49.

Osterwalder, A., Pigneur, Y. (2013) Designing Business Models and Similar Strategic Objects: The Contribution of IS. Journal of the Association for Information Systems, 14, 237-244.

Osterwalder, A., Pigneur, Y. (2010) Business Model Generation: A Handbook for Visionaries, Game Changers, and Challengers. US, John Wiley \& Sons. 
Osterwalder, A., Pigneur, Y. \& Tucci, C.L. (2005) Clarifying Business Models: Origins, Present, and Future of the Concept. Communications of the Association for Information Systems, 16(1), 1-40.

Pavia, T.M. (1991) The early stages of new product development in entrepreneurial high-tech firms. Journal of Product Innovation Management, 8(1), 18-31.

Pettigrew, A.M. (1990) Longitudinal Field Research on Change: Theory and Practice. Organization Science, 1(3), 267-292.

Porter, M.E. (2001) Strategy and the Internet. Harvard Business Review, 79(3), 62-78.

Ries, E. (2011) The Lean Startup: How Today's Entrepreneurs Use Continuous Innovation to Create Radically Successful Businesses. NY, Crown Business.

Rosenberg, N. (1998) Uncertainty and Technological Change. In Neef, D., Siesfeld, G.A., Cefola, J. (Eds.) The Economic Impact of Knowledge. Routledge, US. 1734.

Sarasvathy, S.D. (2001) Causation and effectuation: Towards a theoretical shift from economic inevitability to entrepreneurial contingency. Academy of Management Review, 26(2), 243-288.

Sarasvathy, S.D., Dew, N., Velamuri, S.R. \& Venkataraman, S. (2003) Three Views of Entrepreneurial Opportunity. In Act, Z.J. \& Audretsch, D.B. (Eds.) Handbook of Entrepreneurship Research. US, Springer. 77-98.

Sarasvathy, S.D. (2008) Effectuation: Elements of Entrepreneurial Expertise. UK, Edward Elgar Publishing.

Schultz, H. \& Yang, D.J. (1997) Pour your heart into it: How Starbucks built a company one cup at a time. NY: Hyperion.

Sood, A., James, G.M., Tellis, G.J. \& Zhu, J. (2012) Predicting the Path of Technological Innovation: SAW vs. Moore, Bass, Gompertz, and Kryder. Marketing Science, 31(6), 964-979.

Sosna, M., Trevinyo-Rodríguez, R.N. \& Velamuri, S.R. (2010) Business Model Innovation through Trial-and-Error Learning: The Naturhouse Case. Long Range Planning, 43(2-3), 383-407.

Teece, D.J. (2010) Business Models, Business Strategy and Innovation. Long Range Planning, 43(2-3), 172-194.

Tilson, D., Sorensen, C. \& Lyytinen, K. (2013) Platform Complexity: Lessons from the Music Industry. Proceedings of 46th Hawaii International Conference on System Sciences (HICSS), 4625-4634. 
Weick, K.E. (1979) The Social Psychology of Organizing. Addison-Wesley Publishing Company, US.

Yin, R.K. (2009) Case study research: Design and methods. CA: SAGE Publications.

Zott, C., Amit, R. \& Massa, L. (2011) The Business Model: Recent Developments and Future Research. Journal of Management, 37(4), 1019-1042.

Appendix 1. Illustration of the content analysis

[Insert Appendix 1 around here] 